\title{
ANALISIS KETAHANAN 10 GENOTIPE KACANG HIJAU (Vigna radiata L.) ASAL PROVINSI RIAU TERHADAP CEKAMAN SALINITAS
}

\section{Resilience Analysis of 10 Green Bean (Vigna Radiata L.) Genotypes from Riau Province against Salinity Stress}

\author{
Imra Atul Uswah, Herman, Dewi Indriyani Roslim \\ Program Studi Biologi Bidang Genetika Jurusan Biologi \\ Fakultas Matematika dan Ilmu PengetahuanAlam Universitas Riau \\ Email: uswahimraatul@gmail.com \\ [Diterima: Maret 2018; Disetujui April 2018]
}

\begin{abstract}
Mung bean (Vigna radiata L.) is one of the important because it has a high nutritional value, so many Indonesia consumption its crop. The production of mung beans is still relatively low due to the reduced availability of land, so it is necessary to use marginal land such as saline land. Therefore, this study aims to analyze the resistance of 10 mung bean genotypes (Vignaradiata L.) from Riau Province on salinity stress. Mung beans seeds of 10 genotypes were grown in polybags with treatments including Control and Treatment saline $7 \mathrm{~g} / \mathrm{L} \mathrm{NaCl}$ of Dolphin salt with 7 replications for 66 HST. The interval of watering saline treatment was five days on time the plant begins to bloom. All genotypes showed different morphological responses to salinity stress. Characteristic of 10 genotypes of mung beans from Riau Province based on salinity stress treatment was obtained a significantly different result on the character of productive branch number, plant height, flowering period, number of pods, pod length, seed number, 100 seed weight, and root length. The tolerant genotype of the salinity of Rohul origin 1 (RU1) was superior to plant height, flowering period, number of pods, number of seeds, and root volume. Genotypes from Pelalawan $(\mathrm{P})$ for branch character, Inhu (IU) genotype was for long pods and 100 seeds, and Rohul 2 (RU2) genotype was for long root characters.
\end{abstract}

Keywords: Salinestress, Genotype, Morphology, Riau, Vigna radiata L.

\begin{abstract}
ABSTRAK
Kacang hijau (Vigna radiata L.) merupakan salah satu tanaman budidaya yang penting karena memiliki nilai gizi yang tinggi sehingga banyak di konsumsi oleh penduduk Indonesia. Produksi kacang hijau masih tergolong rendah karena ketersediaan lahan yang berkurang sehingga perlu dimanfaatkan lahan marginal seperti lahan salin. Oleh karena itu penelitian ini ditujukan untuk menganalisis ketahanan dari 10 genotipe kacang hijau (Vigna radiata L.) asal Provinsi Riau terhadap cekaman salinitas. Biji kacang hijau dari 10 genotipe ditanam dalam polibag dengan perlakuan diantaranya Kontrol dan Perlakuan salin $7 \mathrm{~g} / \mathrm{L} \mathrm{NaCl}$ garam Dolphin dengan 7 kali ulangan selama 66 HST. Interval penyiraman perlakuan salin lima hari sekali saat tanaman mulai berbunga. Semua genotipe menunjukkan respon morfologi yang berbeda terhadap cekaman salinitas. Ragam karakter dari 10 genotipe kacang hijau asal Provinsi Riau berdasarkan perlakuan cekaman salinitas dapat memperoleh hasil berbeda nyata terhadap karakter jumlah cabang produktif, tinggi tanaman, periode berbunga, jumlah polong, panjang polong, jumlah biji, bobot 100 biji, dan panjang akar. Genotipe yang toleran pada cekaman salinitas asal Rohul 1 (RU1) lebih unggul terhadap karakter tinggi tanaman, periode berbunga, jumlah polong, jumlah biji, serta volume akar. Genotipe asal Pelalawan (P) untuk karakter jumlah cabang, genotipe asal Inhu (IU) untuk karakter panjang polong dan bobot 100 biji, serta genotipe asal Rohul 2 (RU2) untuk karakter panjang akar.
\end{abstract}

Kata kunci: Salinitas, Genotipe, Morfologi, Riau, Vigna radiata L. 


\section{PENDAHULUAN}

Produksi kacang hijau di Riau lebih rendah dibandingkan dengan produksi tanaman pangan lainnya. Produksi kacang hijau di Provinsi Riau mengalami penurunan pada tahun 2015 dari tahun sebelumnya. Produksi kacang hijau tahun 2011 sebesar 995 ton, tahun 2012 sebesar 920 ton, tahun 2013 sebesar 619 ton, tahun 2014 sebesar 645 ton, dan pada tahun 2015 sebesar 576 ton (Badan Pusat Statistik, 2015). Permasalahan yang menghambat dalam pengelolaan tanaman kacang hijau di tingkat petani adalah masih rendahnya produktivitas hasil. Salah satu daerah di Provinsi Riau yang dipengaruhi oleh intrusi air laut adalah Kabupaten Bengkalis. Sebagian besar penduduk di Bengkalis bermata pencaharian sebagai petani (Pemda Bengkalis, 2013).

Peningkatan produksi kacang hijau dapat dilakukan melalui kegiatan seleksi galur yang dapat beradaptasi pada lingkungan yang spesifik, dan mendukung program ekstensifikasi terutama pada lahan marginal, seperti lahan pasang surut, lahan salin dan lahan kering lainnya. Selanjutnya diperlukan teknik budidaya yang sesuai dan penggunaan galur yang tahan untuk mengurangi pengaruh buruk lingkungan marginal (Farid dan Dariati 2003).

Salah satu upaya yang dapatdilakukan untuk menemukan genotipe kacang hijauyang tahan di tanah salinitas tinggi adalah dengan menyeleksi beberapa genotipe kacang hijau di tanah salin dengan memberikan larutan garam dapur $\mathrm{NaCl}$ sebanyak $7 \mathrm{gr} / \mathrm{L}$. Oleh karena itu, perlu dilakukan penelitian terhadap 10 genotipe kacang hijau asal Provinsi Riau tersebut mengenai ketahanannya terhadap cekaman salinitas.

\section{METODE PENELITIAN}

Alat yang digunakan dalam penelitian ini adalah cangkul, alat ukur, alat tulis, timbangan digital, handsprayer, polibag, ember, kamera, dan alat-alat lainnya yang mendukung penelitian ini. Bahan yang digunakan meliputi biji kacang hijau dari 10 genotipe asal Provinsi Riau meliputi: Bengkalis 1 (B1); Bengkalis 2 (B2); Rohul 1 (RU1); Rohul 2 (RU2); Siak (S); Pelalawan (P); Inhu (IU); Inhil (IL); Kampar (K); Rohil (RI), tanah, pasir, garam dapur
( $\mathrm{NaCl}$ Dolphin), akuades, pupuk urea, TSP (triple super phosphate), dan $\mathrm{KCl}$.

Media tanam yang digunakan pada penelitian ini yaitu campuran tanah, pasir dan pupuk kandang sapi dengan perbandingan volume 2:1:1 (Dachlan et al. 2013). Campuran media tanam tanah, pasir dan pupuk kandang sapi di masukkan ke dalam polibag dengan ukuran $8 \mathrm{~kg}$. Polibag masing-masing diisi sebanyak 3 biji kacang hijau. Pemberian $\mathrm{NaCl}$ terlebih dahulu dilakukan dengan melarutkan 7 $\mathrm{g} / \mathrm{LNaCl}$ ke dalam air sebanyak $1000 \mathrm{~mL}$. Setelah itu sebanyak $330 \mathrm{~mL}$ dari $7 \mathrm{~g} / \mathrm{L}$ larutan garam disiram ke tanaman dengan interval penyiraman lima hari sekali saat tanaman mulai berbunga.

Data dari hasil pengamatan selanjutnya dianalisis statistik menggunakan One-way ANOVA pada tingkat signifikansi 95\%dengan menggunakan program SPSS 16.0.

\section{HASIL DAN PEMBAHASAN}

\section{Jumlah Biji Per Polong}

Jumlah biji per polong merupakan salah satu karakter yang dapat mempengaruhi produktivitas pada tanaman kacang hijau, selanjutnya akan mempengaruhi bobot butir gabah. Semakin banyak jumlah biji per polong yang dihasilkan maka produktivitas pada tanaman kacang hijau semakin tinggi.

Nilai rata-rata jumlah biji per polong pada tanaman kacang hijau yang diberi cekaman salinitas lebih tinggi 9,20 biji dibandingkan dengan kontrol 9,10 biji. Hasil dari penelitian pada karakter jumlah biji per polong pada genotipe kacang hijau diperoleh berbeda nyata. Adapun genotipe yang toleransi terhadap cekaman salinitas yaitu Bengkalis 1 (B1), Siak (S), Inhu (IU), dan Rohil (RI) (Tabel $1)$.

Hal ini disebabkan karena pada tanaman kacang hijau dengan perlakuan salinitas memiliki kemampuan atau keunggulan sifat genetik untuk menghasilkan bobot butir gabah yang banyak akibat pengaruh dari salinitas sehingga selanjutnya akan mempengaruhi bobot butir gabah. Pembentukan dan pengisian polong sangat ditentukan oleh sifat genetik tanaman dan beberapa faktor lain seperti pertumbuhan tanaman, intensitas cahaya, dan daya hasil suatu varietas (Hidayat 2000). 
Tabel 1.Rata-rata jumlahbiji per polongpada tiap perlakuan cekaman salinitas

\begin{tabular}{lccc}
\multicolumn{1}{c}{ Genotipe } & \multicolumn{2}{c}{ Perlakuan Cekaman } & \multirow{2}{*}{ Kategori } \\
\cline { 2 - 3 } & Kontrol & Salinitas & \\
\hline B1 (Bengkalis1) & 8,17 & 9,46 & T \\
B2 (Bengkalis2) & 9,26 & 8,66 & TT \\
RU1 (Rohul1) & 10,59 & 9,87 & TT \\
RU2 (Rohul2) & 9,81 & 9,16 & TT \\
S (Siak) & 9,19 & 9,91 & T \\
P (Pelalawan) & 8,30 & 7,90 & TT \\
IU (Inhu) & 9,34 & 9,96 & T \\
IL (Inhil) & 9,91 & 9,74 & TT \\
K (Kampar) & 7,93 & 7,63 & TT \\
RI (Rohil) & 8,46 & 9,70 & T \\
Rata-rata & 9,10 & 9,20 & \\
\hline
\end{tabular}

Keterangan: (TT) tidak toleransi. (T) toleransi.

\section{Bobot 100 Biji (g)}

Bobot 100 biji rata-rata pada tanaman kacang hijau yang diberi cekaman salinitas lebih tinggi (6,21 g) dibandingkan dengan kontrol $(5,95 \mathrm{~g})$.

Perlakuan cekaman salinitas menyebabkan perubahan ukuran biji, yaitu perubahan ukuran biji dari sedang menjadi besar pada genotipe B1, RU2, P, dan RI. Sebaliknya, pada genotipe B2, IL, dan K
Terjadi perubahan ukuran biji dari besar menjadisedang. Genotipe yang toleransi terhadap cekaman salinitas yaitu genotipe B1, RU1, RU2, S, P, IU, dan RI.

Bobot 100 biji digunakan untuk menentukan karakter ukuran biji tergolong kecil, sedang, dan besar. Kriteria biji kacang hijau yang baik adalah berukuran besar yaitu dengan berat diatas $6 \mathrm{~g}$ per 100 biji, tidak mengandung biji keras, kandungan protein tinggi, bentuk biji bundar, dan warna biji hijau kusam (Suhartina 2005).

Tabel 2. Rata-rata bobot 100 bijipada tiap perlakuan cekaman salinitas

\begin{tabular}{lccccc}
\hline \multirow{2}{*}{ Genotipe } & \multicolumn{3}{c}{ Perlakuan } & \\
\cline { 2 - 5 } & \multicolumn{3}{c}{ Kontrol } & \multirow{2}{*}{ Kategori } \\
\cline { 2 - 5 } & Bobot 100 & Ukuran & Bobot 100 & Ukuran \\
& Biji & Biji & Biji & Biji & T \\
\hline B1 (Bengkalis 1) & 5,84 & Sedang & 7,23 & Besar & TT \\
B2 (Bengkalis 2) & 6,07 & Besar & 5,84 & Sedang & T \\
RU1 (Rohul 1) & 5,57 & Sedang & 5,97 & Sedang & T \\
RU2 (Rohul 2) & 5,43 & Sedang & 6,80 & Besar & T \\
S (Siak) & 5,16 & Sedang & 5,46 & Sedang & T \\
P (Pelalawan) & 5,06 & Sedang & 6,30 & Besar & T \\
IU (Inhu) & 6,90 & Besar & 7,19 & Besar & TT \\
IL (Inhil) & 7,10 & Besar & 5,50 & Sedang & TT \\
K (Kampar) & 6,71 & Besar & 5,67 & Sedang & T \\
RI (Rohil) & 5,67 & Sedang & 6,16 & Besar & \\
\hline Rata-rata & 5,95 & & 6,21 & & \\
\hline
\end{tabular}

Keterangan: (TT) tidak toleransi, (T) toleransi. 


\section{Panjang Akar (cm)}

Karakter panjang akar pada perlakuan cekaman salinitas dan kontrol diperoleh hasil dengan nilai rata-rata kontrol 24,91 cm lebih tinggi dibandingkan dengan perlakuan cekaman salinitas 13,51 cm (Tabel3). Keseluruhan genotipe tidak toleransi terhadap cekaman salinitas (Tabel 3).

Panjang akar pada perlakuan kontrol lebih panjang dibandingkan dengan salinitas, hal ini terjadi karena adanya pengurangan pada panjang akar akibat perlakuan cekaman salinitas yang mempengaruhi perkembangan akar pada tanaman kacang hijau, sehingga selsel meristem akar sensitif terhadap garam sementara aktivitas mitosis sel-sel tersebut sangat mempengaruhi untuk pertumbuhan akar (Cheeseman 1988). Tanaman berakar panjang akan memiliki kemampuan yang lebih baik dalam mengabsorbsi air dibandingkan dengan tanaman berakar pendek (Palupi dan Dedywiryanto 2008).

Tabel 3.Rata-rata panjang akar $(\mathrm{cm})$ pada tiap perlakuan cekaman salinitas

\begin{tabular}{|c|c|c|c|}
\hline \multirow{2}{*}{ Genotipe } & \multicolumn{2}{|c|}{ Perlakuan Cekaman } & \multirow{2}{*}{ Kategori } \\
\hline & Kontrol & Salinitas & \\
\hline B1 (Bengkalis1) & 28,00 & 10,71 & TT \\
\hline B2 (Bengkalis2) & 28,14 & 12,50 & TT \\
\hline RU1 (Rohul1) & 29,71 & 16,14 & TT \\
\hline RU2 (Rohul2) & 29,36 & 17,86 & $\mathrm{TT}$ \\
\hline S (Siak) & 34,64 & 13,71 & TT \\
\hline P (Pelalawan) & 31,43 & 14,00 & $\mathrm{TT}$ \\
\hline IU (Inhu) & 18.57 & 13,71 & TT \\
\hline IL (Inhil) & 20,29 & 15,71 & $\mathrm{TT}$ \\
\hline K (Kampar) & 16,57 & 10,57 & TT \\
\hline RI (Rohil) & 12,43 & 10,14 & TT \\
\hline Rata-rata & 24,91 & 13,51 & \\
\hline
\end{tabular}

Keterangan: (TT) tidak toleransi.

Nilai persentase penghambatan panjang akar ini menunjukkan bahwa salinitas mempengaruhi hasil panjang akar tanaman kacang hijau. Berdasarkan hasil persentase penghambatan pertumbuhan panjang akar (Tabel 4), kesepuluh genotipe dibagi kedalam 3 kelompok, dengan kriteria nilai persentase penghambatan panjang akar $<50 \%$ tergolong toleran; 50-60\% tergolong moderat; dan > 60\% tergolong sensitif. Genotipe dengan nilai persentase penghambatan paling kecil yaitu Rohil (RI), Inhil (IL), Inhu (IU), Kampar (K), Rohul 1 (RU1), dan Rohul 2 (RU2) tergolong toleran, genotipe Pelalawan $(\mathrm{P})$ dan Bengkalis 2 (B2) tergolong moderat, dan genotipe Siak (S) dan Bengkalis 1 (B1) tergolong sensitif.

Tabel 4. Persentase penghambatan panjang akar $(\mathrm{cm})$ dalam kondisi tercekam

\begin{tabular}{lc}
\hline \multicolumn{1}{c}{ Genotipe } & Rata-rata \\
\hline B1 (Bengkalis1) & 61,76 \\
B2 (Bengkalis2) & 55,58 \\
RU1 (Rohul1) & 45,67 \\
RU2 (Rohul2) & 39,17 \\
S (Siak) & 60,42 \\
P (Pelalawan) & 55,46 \\
IU (Inhu) & 26,17 \\
IL (Inhil) & 22,57 \\
K (Kampar) & 36,21 \\
RI (Rohil) & 18,42 \\
\hline Rata-rata & 42,14 \\
\hline
\end{tabular}




\section{KESIMPULAN}

Genotipe yang toleran pada cekaman salinitas asal Rohul 1 (RU1) lebih unggul terhadap karakter jumlah biji. Genotipe asal Inhu (IU) untuk karakter bobot 100 biji, serta genotipe asal Rohul 2 (RU2) untuk karakter panjang akar.

Genotipe dengan nilai persentase penghambatan panjang akar paling kecil yaitu Rohil (RI), Inhil (IL), Inhu (IU), Kampar (K), Rohul 1 (RU1), dan Rohul 2 (RU2) tergolong toleran, genotipe Pelalawan $(\mathrm{P})$ dan Bengkalis 2 (B2) tergolong moderat, dan genotipe Siak (S) dan Bengkalis 1 (B1) tergolong sensitif.

\section{UCAPAN TERIMA KASIH}

Penulis mengucapkan terima kasih kepada DP2M DIKTI yang telah mendanai penelitian ini melalui Hibah tahun 2017 atas nama Dr. Herman, SP, M.Sc.

\section{DAFTAR PUSTAKA}

Badan Pusat Statistik. 2015. Produksi Tanaman Pangan Menurut Jenis dan Kabupaten/Kota. http://riau.bps.go.id/linkTabelStatis/view/ id/130. [25 November 2017]

Cheeseman JM. 1988. Plant Physiol. hlm 87 547. Depok: Universitas Indonesia.

Dachlan, A,. Nurlina K., Kurnia S.A. 2013. Uji Ketahanan Salinitas Beberapa Varietas Jagung (Zea mays L.) dengan Menggunakan Agen Seleksi $\mathrm{NaCl}$. 1(1):9-17.

Farid, B.M., Dariati, T. 2003. Hubungan Antara Hasil Biji dengan Sifat Agronomis Kacang Hijau pada Media Salin. Jurnal Agrivigor. 3 (20):171-178.

Hidayat, O.O, Ismunadji, Sumarno, Syam, M, Manurung, S.O., Yuswandi (peny). 2000. Morfologi Tanaman Kedelai. Bogor: Balai Penelitian dan Pengembangan Pertanian. hlm 74-76.

Palupi, ER., Dedywiryanto, Y. (2008). Kajian Karakter Toleransi Cekaman Kekeringan pada Empat Genotipe Bibit Kelapa Sawit (Elaeis guineensis Jacq). Bul Agron 36(1): 24-32
Pemda Bengkalis. 2013. Situs Resmi Pemerintah Kabupaten Bengkalis. Profil. http://www.bengkaliskab.go.id/. $\quad$ [28 November 2017].

Suhartina. 2005. Deskripsi Varietas Unggul Kacang-Kacangan dan Umbi-Umbian. Malang: Balai Penelitian Tanaman Kacang-kacangan dan Umbi-umbian. 
